\title{
Pulmonary complications in patients with liver cirrhosis
}

\author{
Fabian Benz, Raphael Mohr, Frank Tacke, Christoph Roderburg \\ Charité University Medicine Berlin, Department of Hepatology \& Gastroenterology, Campus Virchow Klinikum \\ and Campus Charité Mitte, Berlin, Germany
}

\section{ABSTRACT}

Patients with advanced chronic liver diseases, particularly with decompensated liver cirrhosis, can develop specific pulmonary complications independently of any pre-existing lung disease. Especially when dyspnea occurs in combination with liver cirrhosis, patients should be evaluated for hepato-pulmonary syndrome (HPS), porto-pulmonary hypertension (PPHT), hepatic hydrothorax and spontaneous bacterial empyema, which represent the clinically most relevant pulmonary complications of liver cirrhosis. Importantly, the pathophysiology, clinical features, diagnosis and the corresponding therapeutic options differ between these entities, highlighting the role of specific diagnostics in patients with liver cirrhosis who present with dyspnea. Liver transplantation may offer a curative therapy, including selected cases of HPS and PPHT. In this review article, we summarize the pathogenesis, clinical features, diagnostic algorithms and treatment options of the 4 specific pulmonary complications in patients with liver cirrhosis.

Key words: chronic liver diseases, decompensated liver cirrhosis, dyspnea, hepatopulmonary syndrome (HPS), portopulmonary hypertension (PPHT), hepatic hydrothorax, spontaneous bacterial empyema

\section{INTRODUCTION}

Cirrhotic transformation of the liver is the characteristic outcome in the long run of chronic hepatic inflammation. Liver cirrhosis might occur as an end stage consequence of manifold infectious, toxic, metabolic, or autoimmune conditions such as viral hepatitis, alcoholism, non-alcoholic steatohepatitis (NASH), autoimmune hepatitis (AIH), primary sclerosing cholangitis (PSC), primary biliary cholangitis $(\mathrm{PBC})$, or a variety of storage disorders like hemochromatosis, Wilson's disease and alpha1-antitrypsin deficiency. ${ }^{[1]}$ The functional and anatomic consequences include: 1) hepatic insufficiency with restricted synthesis and metabolic functions of the liver, 2) portal hypertension, and 3) consecutively formation of intrahepatic porto-systemic shunts between portal vessels and hepatic veins. ${ }^{[2,3]}$ If clinically relevant complications and sequelae of portal hypertension occur (e.g., ascites, variceal bleeding, splenomegaly, hepatorenal syndrome) as well as deteriorating liver function (e.g., limited formation of coagulation factors, limited degradation of ammonia with development of hepatic encephalopathy), this is called decompensated liver cirrhosis. ${ }^{[2,3]}$

Pulmonary complications may occur in patients either with or without decompensation of liver disease. These specific disorders need to be distinguished from primary lung diseases, such as chronic obstructive pulmonary disease (COPD), which may occur in patients with liver diseases as well, but are not pathogenically related to the liver cirrhosis. The most frequent and clinically specific relevant pulmonary complications are hepatic hydrothorax, spontaneous pulmonary empyema, hepato-pulmonary syndrome, and portopulmonary hypertension. In the present manuscript, we aimed to give an overview of pulmonary complications of liver cirrhosis and highlight possible treatment strategies.

\section{HEPATIC HYDROTHORAX}

Hepatic hydrothorax $(\mathrm{HH})$ is defined as a pleural transudate in patients with liver cirrhosis and/or portal hypertension, 
whenever other etiologies of pleural effusion (e.g., renal or cardiac decompensation, or primary pulmonal disorder) have been ruled out (Table 1). ${ }^{[4,5]}$ The presence of an $\mathrm{HH}$ is associated with higher morbidity and mortality when compared to ascites alone. ${ }^{[6]} \mathrm{A}$ recent study showed that the appearance of $\mathrm{HH}$ is associated with a median survival of $8-12$ months. ${ }^{[7]}$

The exact pathophysiological mechanisms involved are yet not completely understood. Since most patients have coexisting ascites and hydrothorax, the currently favored hypothesis is based on a transdiaphragmatic fluid shift from the peritoneal into the pleural cavity via diaphragmatic defects. Patients may present microscopic or even macroscopic diaphragmatic lesions, ${ }^{[8]}$ which are observed more frequently in the right hemidiaphragm, being thinner and less muscular than the left side. A study including 1038 patients with advanced liver cirrhosis described the incidence of $\mathrm{HH}$ with $5 \%$, mostly right-sided $(70 \%)$, less frequently left-sided $(12 \%)$, or bilateral $(18 \%){ }^{[9]}$ Nevertheless, isolated occurrence of $\mathrm{HH}$ without ascites may be conditioned by the negative intrathoracic pressure generated during inspiration, promoting fluid accumulation in the pleural space rather than in the abdominal cavity. ${ }^{[10]}$ Ascites is coexisting in $80 \%$ of cases with $\mathrm{HH}$ but is not required for diagnosis. ${ }^{[1]]}$

Patients may present severe clinical symptoms, even with only a little amount of pleural effusion due to the restrictive pattern of pulmonary function. Clinical symptoms are not very specific and patients may report dyspnea at rest (34\%), increased dyspnea after exertion $(7 \%)$, non-productive cough $(22 \%)$, pleuritic chest pain $(8 \%)$, or dizziness and fatigue as a consequence of hypoxemia $(7 \%)$. Respiratory failure and tension hydrothorax with consecutive cardiac failure have been described. ${ }^{[7,12,13]}$

Diagnostic thoracentesis to distinguish between transudate and exudate should be performed at initial diagnosis and if recurrent. ${ }^{[7]}$ Complications of diagnostic pleural puncture are scarce (e.g., pneumothorax $<5 \%$, bleeding $<1 \%$, vasovagal reactions $<1 \%)^{[14,15]}$ and can be further diminished by using sonographic guided puncture techniques. Prophylactic substitution of blood products (platelet concentrates, fresh frozen plasma, or coagulation factors) should only be considered in patients with grave coagulation disorders (INR $>3$, platelets $\left.<25,000 / \mathrm{mm}^{3}\right) \cdot{ }^{[16]}$

$\mathrm{HH}$ is characterized by a total cell count of polymorphonuclear cell $(\mathrm{PMN})<250 / \mu \mathrm{L}$, a total protein concentration $<2.5 \mathrm{~g} / \mathrm{dL}$, an albumin gradient (serum - pleural fluid) $>1.1 \mathrm{~g} / \mathrm{dL}$, or an albumin quotient (pleural fluid/serum) $<0.6$. Further optional parameters indicating $\mathrm{HH}$ are protein quotient $<0.5$ (pleural fluid/ serum), a LDH gradient $<0.6$ (serum - pleural fluid), and similar $\mathrm{pH}$ value as well as glucose concentration in serum and pleural fluid. ${ }^{[17,18]}$ As already mentioned above, renal, cardiac, and primary pulmonal causes of pleural transudate must been ruled out. Useful tools can be echocardiography, urine analytics, computed tomography angiography, cytological or microbiological work-up (in case of suspected malignancy or tuberculosis, respectively)

\begin{tabular}{|c|c|c|}
\hline & Hepatic hydrothorax & Spontaneous bacterial empyema \\
\hline Definition & $\begin{array}{l}\text { Transudative pleural effusion } \\
+ \text { liver cirrhosis and/or portal hypertension } \\
+ \text { exclusion of other reasons of pleural effusion (e.g., primary } \\
\text { renal, cardiac and pneumological disease) }\end{array}$ & $\begin{array}{l}\text { Spontaneous infection of a preexisting hepatic } \\
\text { hydrothorax }\end{array}$ \\
\hline Prevalence & $5 \%$ to $15 \%$ in patients with cirrhosis & $\begin{array}{l}\text { In } 2 \% \text { of cirrhotic patients, and } 10 \%-16 \% \\
\text { among } \\
\text { cirrhotic patients with hepatic hydrothorax }\end{array}$ \\
\hline Diagnostic & Sonography, chest X-ray, diagnostic thoracentesis & diagnostic thoracentesis \\
\hline $\begin{array}{l}\text { Diagnostic criteria } \\
\text { of the pleural } \\
\text { effusion }\end{array}$ & $\begin{array}{l}\text { 1. a total cell count of } \mathrm{PMN}<250 / \mu \mathrm{L} \\
\text { 2. a total protein concentration }<2.5 \mathrm{~g} / \mathrm{dL} \\
\text { 3. an albumin gradient }>1.1 \mathrm{~g} / \mathrm{dL} \text { between serum and pleural } \\
\text { fluid or an albumin quotient (pleura/serum) }<0.6 \text {. } \\
\text { Optional: a protein quotient }<0.5 \text { (pleura/serum), an } \mathrm{LDH} \\
\text { gradient }<0.6 \text { (pleura/serum) and comparable values for } \mathrm{pH} \text { and } \\
\text { glucose in serum and pleural fluid. }\end{array}$ & $\begin{array}{l}\text { Total cell count of PMN of }>250 / \mu \mathrm{L} \\
+ \text { a positive pathogen detection } \\
\text { or } \\
\text { Total cell count of PMN }>500 / \mu \mathrm{L} \\
+ \text { a negative pathogen detection }\end{array}$ \\
\hline Clinical features & $\begin{array}{l}\text { (depending on the amount of pleural effusion) } \\
\text { dyspnea at rest/after exertion, non-productive cough, pleuritic } \\
\text { chest pain, signs of hypoxemia, respiratory failure and acute } \\
\text { tension hydrothorax with cardiac failure }\end{array}$ & $\begin{array}{l}\text { Fever, encephalopathy, hepatorenal } \\
\text { decompensation }\end{array}$ \\
\hline Therapy options & $\begin{array}{l}\text { Sodium restriction, diuretic therapy (furosemide, spironolactone), } \\
\text { large-volume paracentesis, thoracentesis, TIPS, liver } \\
\text { transplantation, pleurodesis }\end{array}$ & $\begin{array}{l}\text { Intravenous antibiotic and albumin substitution, } \\
\text { thoracic drainage }\end{array}$ \\
\hline
\end{tabular}

PMN: polymorphonuclear cell; TIPS: transjugular intrahepatic portosystemic shunt. 
or specific laboratory tests when chylothorax (triglyceride level) or pancreatitis (amylase concentration) are considered likely differential diagnoses.

Ultra-sonography and X-ray are valid diagnostic tools. Nevertheless, a computed tomography of the thorax should be performed in order to rule out mediastinal, pulmonary, or pleural malignancies. Complementary abdominal imaging including Doppler sonography of splanchnic veins is recommendable. In some cases, intraperitoneal injection of $99 \mathrm{mTc}$-sulphur colloid or $99 \mathrm{mTc}$-human serum albumin may be helpful and confirms the diagnosis of $\mathrm{HH}$ when radioisotopes migrate from the peritoneal cavity into the pleural space. ${ }^{[19,20]}$

Therapy of $\mathrm{HH}$ is based on the therapeutic principles of ascites treatment. Sodium restriction, diuretics, and large-volume paracentesis improve respiratory function and may sufficiently relive symptoms. ${ }^{[21,22]}$ In view of higher complication rates of therapeutic thoracentesis (as compared to paracentesis), it should only be performed if symptoms persist. ${ }^{[23]}$ In order to avoid the development of re-expansion pulmonary edema, pleural puncture volume should not exceed 1.5-2 L/puncture. Substitution of 6-8 g albumin per liter may be beneficial, although no clear evidence for this practice exists. Complications of thoracentesis include pneumothorax, hemothorax, vasovagal episodes, pain at puncture site, laceration of liver or spleen, empyema and subcutaneous emphysema. $[24,25]$

A transjugular intrahepatic portosystemic shunt (TIPS) may be beneficial in cases of therapy resistant HH. Decreasing portal hypertension, this approach eliminates a major pathophysiological cause of $\mathrm{HH} .{ }^{[26]}$ A meta-analysis of 198 patients showed complete recovery in 56\% and a partial improvement in $18 \% .{ }^{[27]}$ Contraindications for TIPS in $\mathrm{HH}$ are similar to those for other indications including severe liver dysfunction, poorly controlled hepatic encephalopathy, right-sided heart failure, pulmonary hypertension and complete portal vein thrombosis.

When TIPS is not feasible, pleurodesis (e.g., applying talcum, OK-432, picibanil, minocycline) may be performed. ${ }^{[28,29]}$ Meta-analysis showed an initial success rate of $70-75 \%$, nevertheless, relapse occurs in up to $25 \%$ and complications (especially empyema and renal failure) were observed in up to $80 \%{ }^{[29]}$ If diaphragmatic lesions are identified, surgical treatment with pleural flaps or mesh reinforcement have been described. ${ }^{[30,31]}$ Liver transplantation is the only curative therapeutic option for $\mathrm{HH}$. However, higher rates of postoperative infections and reduced survival rates were described, emphasizing the relevance of $\mathrm{HH}$ as an adverse prognostic factor in cirrhosis. ${ }^{[32]}$
A continuous transcutaneous thoracic drainage is not recommended because of massive protein and electrolyte depletion, risk of infection, renal failure and bleeding. ${ }^{[33,34]}$ Furthermore, studies show increased risk of mortality in patients who did receive a continuous thoracic drainage when compared to patients who underwent (recurrent) thoracentesis. ${ }^{[35]}$

\section{SPONTANEOUS BACTERIAL EMPYEMA}

Spontaneous bacterial empyema (SBEM) is a specific complication of $\mathrm{HH}$, analogous to spontaneous bacterial peritonitis (SBP) in the context of ascites (Table 1). ${ }^{[36]}$

An observational study following 3390 patients with cirrhosis over four years described SBEM in $2.4 \%$ of the overall population and in 10-16\% of patients with preexisting hydrothorax, with an associated mortality of $38 \%{ }^{[37]}$ Recently, it was demonstrated that approximately $50 \%$ of patients with $\mathrm{HH}$ and pre-existing SBP develop SBEM. ${ }^{[38]}$ Further risk factors associated with SBEM are poor liver function, low total protein and albumin concentrations in serum and/or pleural fluid, and low C3 complement in pleural fluid. ${ }^{[39,40]}$ Mortality rate is described with $20-38 \%$. Germ spectrum associated with SBEM is comparable to that with SBP and frequently includes Escherichia coli, Klebsiella, Streptococcus, or Enterococcus. ${ }^{[3]}$ Of note, cirrhotic patients, particularly patients with a history of frequent hospitalizations, are often affected by infections with multidrug resistant bacterial strains, ${ }^{[4]}$ which account for approximately one third of bacterial infections in hospitalized patients with liver cirrhosis. ${ }^{[42]}$ Clinical symptoms are non-specific, a cardinal symptom is fever with the clinical picture of decompensated liver cirrhosis.

When suspected, a diagnostic thoracentesis should be performed. Diagnosis of SBEM is based on a total polymorphonuclear $(\mathrm{PMN})$ cell count $>250 / \mu \mathrm{L}$ in combination with positive microbiological finding, or a total PMN cell count $>500 / \mu \mathrm{L}$ when cultures of pleural fluid remain negative. However, microbiological workup remains negative in about two third of the cases. ${ }^{[39,40]}$ Imaging procedures, especially contrast-enhanced computed tomography, can support the diagnosis and identify pleural abscess formation that may require immediate drainage.

Therapy of SBEM, similar to that of SBP, consists in intravenous administration of 3 rd generation cephalosporins (such as ceftriaxone $2 \mathrm{~g}$ every 24 hours for 7 to 10 days) and albumin substitution. ${ }^{[37]}$ In countries with high rates of antibiotic resistance, piperacillin/tazobactam or carbapenem should be considered. ${ }^{[43]}$ Antibiotics should be adjusted 
according to local resistances and should be initiated right after pleural fluid sampling. ${ }^{[4]]}$ In case of purulent SBEM thoracic drainage, local application of streptokinase, or video-assisted thoracoscopic surgery (VATS) in case of chambered effusion should be evaluated. ${ }^{[38]}$

\section{HEPATO-PULMONARY SYNDROME}

Hepato-pulmonary syndrome (HPS) is defined as gas exchange disorder resulting from intrapulmonary vascular dilatation in patients with advanced liver disease, portal hypertension or portosystemic shunting. ${ }^{[45]}$ However, HPS may also occur in acute liver failure such as ischemic or viral hepatitis and portal vein thrombosis. ${ }^{[46,47]}$ Intrapulmonary vascular dilatation can be diffused or localized, rarely pleural and/or pulmonary arteriovenous shunts occur.

Observational studies reported a correlation between the presence of HPS and more severe liver disease. ${ }^{[48,49]}$ The prevalence of HPS among patients with end stage liver disease is about $5-32 \% \cdot{ }^{[48,50]}$ Nevertheless, isolated intrapulmonary vascular dilatation can be found in up to $50-60 \%$ of patients with liver cirrhosis, but mostly without influencing arterial oxygenation. ${ }^{[11,52]}$ Mortality seems to be doubled in cirrhotic patients with HPS compared to nonHPS cirrhotic patients, independent of age, MELD-score, hypoxemia, and comorbidities. ${ }^{[33]}$

Pathophysiologically, HPS develops due to changes in pulmonary vessels leading to a lack of arterial oxygenation. The potent vasodilators nitrogen (NO), endothelin-1 (ET1), and carbon monoxide (CO) seem to play a crucial role. ${ }^{[54]} \mathrm{NO}$ is increasingly produced in the pulmonary circulation after the activation of both endothelial nitric acid synthase (eNOS) and inducible NOS (iNOS). ${ }^{[5]}$ The underlying liver cirrhosis and portal hypertension cause an increased hepatic production of ET-1. ${ }^{[56]}$ ET-1 enhances the activation of eNOS and triggers monocyte accumulation through endothelin B receptor overexpression in the pulmonary vascular endothelium. ${ }^{[57,58]}$ Monocytes and monocyte-derived macrophages express iNOS and produce heme oxygenase-1, leading to increased CO production and further vasodilation. ${ }^{[5]}$ Additional vasoactive mediators are released by increased bacterial translocation due to portal hypertension (intestinal endotoxemia), whereas their clearance is hampered because of decreased liver function. ${ }^{[60,61]}$ Circulating monocytes enhance neoangiogenesis by producing and upregulating CX3CL1 and vascular endothelial growth factor A (VEGF). ${ }^{[2,63]}$ Histopathologically, these pulmonary changes are reflected by a significant dilatation of precapillary and capillary vessels (15 to 500 microns, normal range is 8 to 15 microns), the formation of arteriovenous and/or portopulmonary shunts. ${ }^{[6,65]}$ Both, vasodilatation and neoangiogenesis play a crucial role and lead to a mismatch between increased perfusion and unaltered alveolar ventilation. This favors alveolar-capillary diffusion limitation, leading to a right-left shunt and ultimately causes hypoxia. ${ }^{[45]}$

Clinical symptoms of HPS are non-specific. More than $80 \%$ of HPS patients present dyspnea in the setting of chronic liver disease. Especially while sleeping, episodes of significant desaturation may occur, even if daytime hypoxemia is moderate. ${ }^{[6]]}$ Tachypnea, polypnea and signs of chronic hypoxia such as digital clubbing and cyanosis are found in up to $20 \%$ of patients at the time of diagnosis. ${ }^{[53]}$ As vascular dilatation predominately affects basal lung sections, platypnea ( $=$ increased breathing difficulty when sitting with improvement when lying down) or orthodeoxia (= decrease in $\mathrm{PaO} 2$ of $5 \%$ or $4 \mathrm{mmHg}$ when changing position from lying to sitting) is found in about $25 \%$ of patients. ${ }^{[67-69]}$

As an initial screening test, pulse oximetry with a cut-off of $96 \%$ saturation at room air can be used. SpO2 $<96 \%$ was found to be highly sensitive (100\%) and specific (88\%) for detecting HPS in patients with a $\mathrm{PaO} 2<70 \mathrm{mmHg} \cdot{ }^{[70]}$ Patients with HPS generally present normal findings in spirometry and lung volume measurements (unless there is coexisting obstructive or restrictive lung disease), so that pulmonary function testing is usually not helpful in the diagnostic work-up but may be used to rule out differential diagnoses. The diffusion capacity for carbon monoxide (DLCO) is typically impaired. ${ }^{[71]}$ In the arterial blood gas analysis, an increased alveolar-arterial oxygen partial pressure difference $(\mathrm{AaDO} 2) \geq 15 \mathrm{mmHg}$ (at age $\leq 64$ years) and $\geq 20 \mathrm{mmHg}$ (at age $>64$ years) can be found. ${ }^{[72]}$ Based on the arterial $\mathrm{PaO} 2$ at sea level, HPS is categorized by the degree of hypoxemia into mild $(\mathrm{PaO} 2 \geq$ $80 \mathrm{mmHg}$ ), moderate (PaO2 60-79 mm Hg), severe (PaO2 $50-59 \mathrm{mmHg})$, and very severe $(\mathrm{PaO} 2<50 \mathrm{mmHg}){ }^{[45]}$

Transthoracic or transesophageal echocardiography may be used to detect intrapulmonary vascular dilatation. ${ }^{[45,51,65]}$ For this purpose, a normally non-respirable ultrasound contrast medium (shaken $0.9 \%$ saline solution to produce sonographically visible microbubbles $>10 \mu \mathrm{m}$ in diameter) is injected via a peripheral vein. In the presence of a functional shunt due to dilated pulmonary vessels, the detection of the contrast medium in the left heart usually takes place after $2-5$ heartbeats (in the case of an intracardiac shunt, such as open foramen ovale or atrial septal defect (ASD), usually after 1-2 heartbeats). ${ }^{[73]}$ Further techniques to detect intrapulmonary shunts are scintigraphy, computed tomography and pulmonary arteriography. Lung perfusion scintigraphy uses $99 \mathrm{~m}$-Technetium-macroaggregated human albumin (MAA) (20-50 $\mu \mathrm{m}$ size), which can only cross pulmonary circulation via a right-left shunt. ${ }^{[74]}$ An increased 
shunt fraction of $>6 \%$ supports evidence that HPS is the major contributor to hypoxemia. ${ }^{[7]}$ Shunt fractions of $>$ $20 \%$ indicate very severe HPS $(\mathrm{PaO} 2<50 \mathrm{mmHg})$ and are associated with high mortality..$^{[7]}$ Computed tomography or invasive pulmonary arteriography can visualize vascular dilatations and differentiate diffuse shunts (HPS type I) from focal shunts (HPS type II). ${ }^{[75,77]}$ Pulmonary angiography should only be performed in patients with severe forms of HPS, when arteriovenous shunts seem suitable for embolization. ${ }^{[43]}$ Table 2 summarizes the features and diagnostic findings of HPS.

Currently, there is no established conservative drug therapy for HPS. Effectiveness of invasive reduction of portal hypertension by TIPS is controversially discussed. ${ }^{[78]}$ Interestingly, smaller case series provide evidence that surgical cavoplasty or angiographic embolization of portosystemic shunts improve arterial oxygenation and HPS. ${ }^{[7,80]}$ Upon this contradictory data, no clear recommendations can be given. Long-term supplemental oxygen therapy (LTOT) improves clinical symptoms of intrapulmonary vascular shunts (e.g., dyspnea, fatigue, desaturation)..$^{[43]}$

Indications for initiation of LTOT in the setting of HPS are similar to those used in patients with other chronic pulmonary diseases, namely $\mathrm{PaO} 2 \leq 55 \mathrm{mmHg}$ or $\mathrm{SaO} 2 \leq$ $88 \%$. Patients with milder forms of HPS require periodic monitoring (pulse oximetry and arterial blood gas analysis) every 6 to 12 months to detect worsening of HPS and to evaluate treatment options in time. The only curative treatment option is liver transplantation (LT). Patients with HPS presenting $\mathrm{PaO}_{2}<60 \mathrm{mmHg}$ should be evaluated for LT. Data from observational studies demonstrated resolution of HPS with improved oxygenation and reduced shunt volumes in about $80 \%$ of patients within 6 to 12 months after LT. ${ }^{[81,82]}$ Only patients with severe hypoxemia $(\mathrm{PaO} 2$ $<45-50 \mathrm{mmHg}$ ) are associated with increased post-LT mortality, and thus, $\mathrm{LT}$ is contraindicated in those patients. ${ }^{[83]}$

\section{PORTO-PULMONARY HYPERTENSION}

Portopulmonary hypertension (PPHT) is a rare complication of end-stage liver disease and is defined as pulmonary arterial hypertension (PAH) that is associated with portal hypertension (Table 2). ${ }^{[45,84]}$ Other etiologies of the PAH (e.g., collagen vascular disease, chronic heart failure, human immunodeficiency virus, primary forms of $\mathrm{PAH}$, or drug-induced $\mathrm{PAH}$ ) and differential diagnosis of primary pulmonary disease (e.g., chronic thromboembolism, chronic lung disease) must be ruled out.

The pathogenesis of PPHT is still unknown. A broad variety of pathophysiological hypotheses were proposed: 1) imbalance of vasoconstrictive and vasodilatory mediators due to impaired liver metabolization, 2) hyperdynamic pulmonary circulation with increased sheer stress on the pulmonary vascular wall, 3) increased local inflammation due to elevated cytokine levels associated with the cirrhotic liver, 4) thromboembolisms that originated from the portal venous system, 5) genetic predisposition. In summary, a remodeling process of the pulmonary vasculature leads to increased pulmonary vascular resistance. Ultimately, this conditions an increased afterload and, in the long run, right-sided heart failure. ${ }^{[85]}$

PPHT and PAH show a similar histopathological picture characterized by media hypertrophy, remodeling processes of the pulmonary artery's lamina muscularis, and in situ thrombosis. ${ }^{[86]}$ These changes go along with a dysregulation of endogenous vasoregulators, increased endothelin- 1 and reduced prostacyclin synthase from pulmonary endothelial cells, proliferation of smooth muscle cells, endothelial activation, and platelet aggregation.

Upon physical examination, an accentuated and split second heart sound, right ventricular heave, right-sided S3 gallop, jugular venous distention, and leg edema may hint at PPHT. ${ }^{[87,88]}$ Electrocardiographic abnormalities include right atrial enlargement, right ventricular hypertrophy, right axis deviation, and/or right bundle branch block. Radiologically, a prominent main pulmonary artery (hilar enlargement) or cardiomegaly may be found. Golden standard for the diagnosis of PPHT is right heart catheterization (RHC). The following criteria are considered diagnostic for PPHT: 1) Elevated mean pulmonary artery pressure (MPAP) $>$ $25 \mathrm{mmHg}$ at rest, 2) normal or low pulmonary artery wedge pressure (PAWP) $\leq 15 \mathrm{mmHg}$ at rest, 3) elevated peripheral vascular resistance (PVR) $>240$ dyn-sec-cm-5 and transpulmonary gradient (TPG) $>12 \mathrm{mmHg} .{ }^{[84]}$ The right ventricular systolic pressure (RVSP) estimated by Doppler echocardiography correlates with the mPAP measured by RHC. ${ }^{[89]}$ It is used as a screening test, because a RVSP > $30 \mathrm{mmHg}$ in Doppler echocardiography has a negative predictive value of $100 \%$, whereas its positive predictive value is $59 \% .{ }^{[90]}$ Based on the mean values of pulmonary artery pressure, PPHT is classified as mild (MPAP 25-35 mmHg), moderate (MPAP 35-45 mmHg), and severe (MPAP $\geq 45 \mathrm{mmHg}) \cdot{ }^{[1]}$

Among patients with cirrhosis, prospective catheterization studies have demonstrated a prevalence of PPHT between $2 \%$ and $10 \%{ }^{\left[{ }^{[9-94]}\right.}$ Female and autoimmune hepatitis $(\mathrm{AIH})$ are associated with an increased risk for PPHT. ${ }^{[88]}$ Notably, similar to what has been demonstrated for HPS, no association between severity of PPHT and severity of liver disease has been found. ${ }^{[88,93]}$ Especially in early PPHT stages $60 \%$ of patients do not present symptoms. ${ }^{[2]}$ 
Benz et al.: Pulmonary complications in patients with liver cirrhosis

\begin{tabular}{|c|c|c|}
\hline & Hepato-pulmonary syndrome & Porto-pulmonary hypertension \\
\hline Definition & $\begin{array}{l}\text { Trias: } \\
\text { 1) a gas exchange disorder } \\
\text { 2) resulting from intrapulmonary vessel dilatation } \\
\text { 3) in the presence of advanced liver disease, } \\
\text { portal hypertension or portosystemic shunting }\end{array}$ & $\begin{array}{l}\text { Pulmonary arterial hypertension } \\
\text { associated with portal hypertension }\end{array}$ \\
\hline Prevalence & $5-32 \%$ & $2-10 \%$ \\
\hline Pathophysiology & $\begin{array}{l}\text { Vasodilatation, intrapulmonary shunts, } \\
\text { neoangiogenesis }\end{array}$ & Vasoconstriction \\
\hline $\begin{array}{l}\text { Diagnostic for } \\
\text { screening }\end{array}$ & $\begin{array}{l}\text { pulse oximetry (cut-off }<96 \% \text { ), } \\
\text { Contrast-enhanced transthoracic } \\
\text { echocardiography }\end{array}$ & Doppler echocardiography \\
\hline $\begin{array}{l}\text { Diagnostic to confirm } \\
\text { the diagnosis }\end{array}$ & $\begin{array}{l}\text { Lung perfusion scintigraphy/pulmonary } \\
\text { angiography }\end{array}$ & Right heart catheterization \\
\hline Severity grades & $\begin{array}{l}\text { based on } \mathrm{PaO} 2 \text { : } \\
\text { mild }(\mathrm{PaO} 2 \geq 80 \mathrm{mmHg}) \\
\text { moderate }(\mathrm{PaO} 260-79 \mathrm{mmHg}) \\
\text { severe }(\mathrm{PaO} 250-59 \mathrm{mmHg}) \\
\text { very severe }(\mathrm{PaO} 2<50 \mathrm{mmHg})\end{array}$ & $\begin{array}{l}\text { Based on mPAP: } \\
\text { mild (mPAP }>25 \text { to }<35 \mathrm{mmHg} \text { ) } \\
\text { moderate (mPAP } \geq 35 \text { to }<45 \mathrm{mmHg} \text { ) } \\
\text { severe (mPAP } \geq 45 \mathrm{mmHg} \text { ) }\end{array}$ \\
\hline Clinical features & $\begin{array}{l}\text { Dyspnea (platypnoea, orthodeoxia), significant } \\
\text { sleep-time oxygen desaturation }\end{array}$ & Dyspnea on exertion, chest pain, syncope \\
\hline Physical examination & Cyanosis, digital clubbing, spider naevi & $\begin{array}{l}\text { Rarely cyanosis, accentuated and split second heart sound, } \\
\text { tricuspid regurgitation murmur, right-sided S3 gallop and } \\
\text { jugular venous distention, leg edema }\end{array}$ \\
\hline Electrocardiography & No specific abnormalities & $\begin{array}{l}\text { right atrial enlargement, right ventricular hypertrophy, right } \\
\text { bundle branch block, axis deviation to the right, signs of RV } \\
\text { hypertrophy }\end{array}$ \\
\hline Blood gas analysis & Moderate to severe hypoxemia & None to moderate hypoxemia \\
\hline Chest X-ray & No abnormalities & Cardiomegaly, Hilar enlargement \\
\hline $\begin{array}{l}\text { Contrast-enhanced } \\
\text { transthoracic } \\
\text { echocardiography }\end{array}$ & $\begin{array}{l}\text { Always positive contrast in the left atrium } \\
\text { approx. } 3-6 \text { heartbeats to the right atrium }\end{array}$ & $\begin{array}{l}\text { Usually negative } \\
\text { (only positive within } 3 \text { heart heartbeats in case of open } \\
\text { foramen oval or ASD) }\end{array}$ \\
\hline $\begin{array}{l}\text { 99mTcMAA- } \\
\text { Scintigraphy }\end{array}$ & Shunt fraction $\geq 6 \%$ & Shunt fraction $<6 \%$ \\
\hline $\begin{array}{l}\text { Pulmonary } \\
\text { hemodynamics }\end{array}$ & Normal to lowered pulmonary vascular resistance & $\begin{array}{l}\text { Increased pulmonary vascular resistance with normal } \\
\text { pulmonary occlusion pressure }\end{array}$ \\
\hline Pulmonary angiograph & $\begin{array}{l}\text { y Normal/"spongy" appearance (type I) } \\
\text { Discrete arteriovenous communications (type II) }\end{array}$ & $\begin{array}{l}\text { Large pulmonary arteries } \\
\text { Distal arterial pruning }\end{array}$ \\
\hline Therapy options & $\begin{array}{l}\text { Long-term supplemental oxygen } \\
\text { Liver transplantation }\end{array}$ & $\begin{array}{l}\text { Prostacyclin pathway agonists, endothelin receptor } \\
\text { antagonists, phosphodiesterase inhibitors and guanylate } \\
\text { cyclase stimulants, Liver transplantation }\end{array}$ \\
\hline
\end{tabular}

ASD: atrial septal defect.

When symptomatic, dyspnea at rest or during exercise, as well as clinical signs of right heart failure are most common. Orthopnea, chest pain, peripheral edema or syncope may develop in the course of disease progression, ${ }^{[87,88,95]}$ often accompanied by symptoms of the underlying liver disease.

Treatment of PPHT focuses on reducing portal hypertension and preventing complications of pulmonary hypertension (e.g., right heart failure, thromboembolism). Because of limited data from patients with PPHT, most of the therapeutic strategies are derived from patients with idiopathic PAH. ${ }^{[96]}$ However, complications of cirrhosis (especially impaired liver function and portal hypertension) must be taken into account when making therapeutic decisions. Patients with PPHT should not routinely receive anticoagulants as thrombocytopenia, coagulopathy or esophageal varices increase the risk of bleeding. ${ }^{[96]}$ Prostacyclin pathway agonists, endothelin receptor antagonists, and nitric oxide-cyclic guanosine monophosphate enhancers (phosphodiesterase inhibitors, guanylate cyclase stimulants) are widely used in PAH. In PPHT, phosphodiesterase-5 inhibitors such as sildenafil and tadalafil are commonly used since their metabolism is not affected by liver dysfunction. Endothelin receptor antagonists (ERAs), particularly bosentan, can be associated with liver toxicity (transaminitis, liver failure, cirrhosis) and should be avoided in moderate to severe liver disease or when aminotransferases are elevated. In contrast to patients with idiopathic PAH calcium canal blockers (CCB) are not useful in PPHT, as here vasoactive response only occurs in $1.7 \%{ }^{[97]}$ Furthermore, hypotension and splanchnic vasodilation induced by CCBs can result in an increased hepatic venous pressure gradient. Patients with PPHT are particularly susceptible to hypotension as systemic vascular 
resistance (SVR) is usually low in cirrhosis and CCB may further reduce SVR resulting in reduced right ventricular (RV) filling and RV failure.

Treatment of portal hypertension is delicate when PPHT coexists. Beta-blockers should be avoided as they reduce right ventricle cardiac output and increase pulmonary vascular resistance (PVR). ${ }^{[8]}$ TIPS increases the right ventricle preload and must be avoided in patients with PAH and PPHT. Liver transplantation is a potential curative treatment option. However, retrospective studies showed increased post-LT mortality in patients with moderate to severe PPHT $(\mathrm{mPAP}>35 \mathrm{mmHg}) \cdot{ }^{[99]}$

\section{CONCLUSIONS}

Dyspnea represents a frequent symptom in patients with liver cirrhosis, but can be related to very different etiologies. After exclusion of extrahepatic cardiopulmonary comorbidities (e.g., congestive heart failure, coronary artery disease, chronic obstructive pulmonary disease, pneumonia and others), specific pulmonary complications of advanced liver diseases must be ruled out. Importantly, the pathophysiology, clinical features, diagnosis and the corresponding therapeutic options differ between the lung-associated complications of liver cirrhosis. At any rate, pulmonary complications like $\mathrm{HH}$, SBEM, HPS or PPHT indicate an adverse prognosis and should prompt to consider liver transplantation. Despite organ transplantation, various specific treatment options exist, which require thorough diagnostic work-up and a mindful patient stratification.

\section{Conflict of Interest}

None declared.

\section{REFERENCES}

1. Schuppan D, Afdhal NH. Liver cirrhosis. Lancet (London, England) 2008; 371: 838-51.

2. Iwakiri Y. Pathophysiology of portal hypertension. Clin Liver Dis 2014; 18: 281-91.

3. Iwakiri Y, Shah V, Rockey DC. Vascular pathobiology in chronic liver disease and cirrhosis - current status and future directions. J Hepatol 2014; 61: 912-24.

4. Krok KL. Hepatic hydrothorax: Current concepts. Clin Liver Dis 2014; 4: 35-7.

5. Lieberman FL, Hidemura R, Peters RL, Reynolds TB. Pathogenesis and treatment of hydrothorax complicating cirrhosis with ascites. Ann Intern Med 1966; 64: 341-51.

6. Atiemo K, Skaro A, Maddur H, Zhao L, Montag S, VanWagner L, et al. Mortality Risk Factors Among Patients With Cirrhosis and a Low Model for End-Stage Liver Disease Sodium Score $(</=15)$ : An Analysis of Liver Transplant Allocation Policy Using Aggregated Electronic Health Record Data. Am J Transplant 2017; 17: 2410-9.
7. Badillo R, Rockey DC. Hepatic hydrothorax: clinical features, management, and outcomes in 77 patients and review of the literature. Medicine 2014; 93: 135-42.

8. Huang PM, Chang YL, Yang CY, Lee YC. The morphology of diaphragmatic defects in hepatic hydrothorax: thoracoscopic finding. J Thorac Cardiovasc Surg 2005; 130: 141-5.

9. Malagari K, Nikita A, Alexopoulou E, Brountzos E, Papathanasiou M, Mitromaras J, et al. Cirrhosis-related intrathoracic disease. Imaging features in 1038 patients. Hepato-gastroenterology 2005; 52: 558-62.

10. Rubinstein D, McInnes IE, Dudley FJ. Hepatic hydrothorax in the absence of clinical ascites: diagnosis and management. Gastroenterology 1985; 88: $188-91$.

11. Gurung P, Goldblatt M, Huggins JT, Doelken P, Nietert PJ, Sahn SA. Pleural fluid analysis and radiographic, sonographic, and echocardiographic characteristics of hepatic hydrothorax. Chest 2011; 140: 448-53.

12. Light RW. Clinical practice. Pleural effusion. N Engl J Med 2002; 346: 1971-7.

13. Kaplan LM, Epstein SK, Schwartz SL, Cao QL, Pandian NG. Clinical, echocardiographic, and hemodynamic evidence of cardiac tamponade caused by large pleural effusions. Am J Respir Crit Care Med1995; 151: 904-8.

14. Xiol X, Castellote J, Cortes-Beut R, Delgado M, Guardiola J, Sese E. Usefulness and complications of thoracentesis in cirrhotic patients. Am J Med 2001; 111: 67-9.

15. Gordon CE, Feller-Kopman D, Balk EM, Smetana GW. Pneumothorax following thoracentesis: a systematic review and meta-analysis. Arch Intern Med 2010; 170: 332-9.

16. Schildhouse R, Lai A, Barsuk JH, Mourad M, Chopra V. Safe and Effective Bedside Thoracentesis: A Review of the Evidence for Practicing Clinicians. J Hosp Med 2017; 12: 266-76.

17. Light RW, Macgregor MI, Luchsinger PC, Ball WC, Jr. Pleural effusions: the diagnostic separation of transudates and exudates. Ann Intern Med 1972; 77: 507-13.

18. Singh A, Bajwa A, Shujaat A. Evidence-based review of the management of hepatic hydrothorax. Respiration 2013; 86: 155-73.

19. Rajnish A, Sudhakar P. Diagnosis of hepatic hydrothorax by Tc-99m sulfur colloid peritoneal scintigraphy. Clin Nucl Med 2001; 26: 888.

20. Bhattacharya A, Mittal BR, Biswas T, Dhiman RK, Singh B, Jindal SK, et al. Radioisotope scintigraphy in the diagnosis of hepatic hydrothorax. J Gastroenterol Hepatol 2001; 16: 317-21.

21. Chang SC, Chang HI, Chen FJ, Shiao GM, Wang SS, Lee SD. Therapeutic effects of diuretics and paracentesis on lung function in patients with non-alcoholic cirrhosis and tense ascites. J Hepatol 1997; 26: 833-8.

22. Angueira CE, Kadakia SC. Effects of large-volume paracentesis on pulmonary function in patients with tense cirrhotic ascites. Hepatology (Baltimore, Md) 1994; 20: 825-8.

23. Castellote J, Xiol X, Cortes-Beut R, Tremosa G, Rodriguez E, Vazquez S. Complications of thoracentesis in cirrhotic patients with pleural effusion. Revista espanola de enfermedades digestivas 2001; 93: 566-75.

24. Collins TR, Sahn SA. Thoracocentesis. Clinical value, complications, technical problems, and patient experience. Chest 1987; 91: 817-22.

25. Grogan DR, Irwin RS, Channick R, Raptopoulos V, Curley FJ, Bartter $\mathrm{T}$, et al. Complications associated with thoracentesis. A prospective, randomized study comparing three different methods. Arch Intern Med 1990; 150: 873-7.

26. Boyer TD, Haskal ZJ. The Role of Transjugular Intrahepatic Portosystemic Shunt (TIPS) in the Management of Portal Hypertension: update 2009. Hepatology (Baltimore, Md) 2010; 51: 306.

27. Ditah IC, Al Bawardy BF, Saberi B, Ditah C, Kamath PS. Transjugular intrahepatic portosystemic stent shunt for medically refractory hepatic hydrothorax: A systematic review and cumulative meta-analysis. World J Hepatol 2015; 7: 1797-806.

28. Cerfolio RJ, Bryant AS. Efficacy of video-assisted thoracoscopic surgery with talc pleurodesis for porous diaphragm syndrome in patients with refractory hepatic hydrothorax. Ann Thorac Surg 2006; 82: 457-9. 
29. Hou F, Qi X, Guo X. Effectiveness and Safety of Pleurodesis for Hepatic Hydrothorax: A Systematic Review and Meta-Analysis. Dig Dis Sci 2016; 61: 3321-34.

30. Huang PM, Kuo SW, Lee JM. Thoracoscopic diaphragmatic repair for refractory hepatic hydrothorax: application of pleural flap and mesh onlay reinforcement. Thorac Cardiovasc Surgeon 2006; 54: 47-50.

31. Huang PM, Kuo SW, Chen JS, Lee JM. Thoracoscopic Mesh Repair of Diaphragmatic Defects in Hepatic Hydrothorax: A 10-Year Experience. Annals Thorac Surg 2016; 101: 1921-7.

32. Endo K, Iida T, Yagi S, Yoshizawa A, Fujimoto Y, Ogawa K, et al. Impact of preoperative uncontrollable hepatic hydrothorax and massive ascites in adult liver transplantation. Surg Today 2014; 44: 2293-9.

33. Orman ES, Lok AS. Outcomes of patients with chest tube insertion for hepatic hydrothorax. Hepatol Int 2009; 3: 582-6.

34. Liu LU, Haddadin HA, Bodian CA, Sigal SH, Korman JD, Bodenheimer HC, Jr., et al. Outcome analysis of cirrhotic patients undergoing chest tube placement. Chest 2004; 126: 142-8.

35. Ridha A, Al-Abboodi Y, Fasullo M. The Outcome of Thoracentesis versus Chest Tube Placement for Hepatic Hydrothorax in Patients with Cirrhosis: A Nationwide Analysis of the National Inpatient Sample. Gastroenterol Res Pract 2017; 2017: 5872068.

36. Tu CY, Chen CH. Spontaneous bacterial empyema. Curr Opin Pulm Med 2012; 18: 355-8.

37. Chen CH, Shih CM, Chou JW, Liu YH, Hang LW, Hsia TC, et al. Outcome predictors of cirrhotic patients with spontaneous bacterial empyema. Liver Int 2011; 31: 417-24.

38. Ewig S, Hoffken G, Kern WV, Rohde G, Flick H, Krause R, et al. [Management of Adult Community-acquired Pneumonia and Prevention - Update 2016]. Pneumologie (Stuttgart, Germany) 2016; 70(3):151-200.

39. Ackerman Z, Reynolds TB. Evaluation of pleural fluid in patients with cirrhosis. J Clin Gastroenterol 1997; 25: 619-22.

40. Sese E, Xiol X, Castellote J, Rodriguez-Farinas E, Tremosa G. Low complement levels and opsonic activity in hepatic hydrothorax: its relationship with spontaneous bacterial empyema. J Clin Gastroenterol 2003; 36: 75-7.

41. Fernández J, Prado V, Trebicka J, Amoros A, Gustot T, Wiest R, et al. Multidrug-resistant bacterial infections in patients with decompensated cirrhosis and with acute-on-chronic liver failure in Europe. J Hepatology 2019; 70: 398-411.

42. Piano S, Singh V, Caraceni P, Maiwall R, Alessandria C, Fernandez J, et al. Epidemiology and Effects of Bacterial Infections in Patients With Cirrhosis Worldwide. Gastroenterology 2019; 156: 1368-80.e1310.

43. EASL Clinical Practice Guidelines for the management of patients with decompensated cirrhosis. J Hepatol 2018; 69: 406-60.

44. Xiol X, Castellvi JM, Guardiola J, Sese E, Castellote J, Perello A, et al. Spontaneous bacterial empyema in cirrhotic patients: a prospective study. Hepatology (Baltimore, Md) 1996; 23: 719-23.

45. Rodriguez-Roisin R, Krowka MJ, Herve P, Fallon MB. Pulmonary-Hepatic vascular Disorders (PHD). Eur Respir J 2004; 24: 861-80.

46. Fuhrmann V, Madl C, Mueller C, Holzinger U, Kitzberger R, Funk GC, et al. Hepatopulmonary syndrome in patients with hypoxic hepatitis. Gastroenterology 2006; 131: 69-75.

47. Kaymakoglu S, Kahraman T, Kudat H, Demir K, Cakaloglu Y, Adalet I, et al. Hepatopulmonary syndrome in noncirrhotic portal hypertensive patients. Dig Dis Sci 2003; 48: 556-60.

48. Younis I, Sarwar S, Butt Z, Tanveer S, Qaadir A, Jadoon NA. Clinical characteristics, predictors, and survival among patients with hepatopulmonary syndrome. Ann Hepatol 2015; 14: 354-60.

49. Kim BJ, Lee SC, Park SW, Choi MS, Koh KC, Paik SW, et al. Characteristics and prevalence of intrapulmonary shunt detected by contrast echocardiography with harmonic imaging in liver transplant candidates. Am J Cardiol 2004; 94: 525-8.

50. Schenk P, Schoniger-Hekele M, Fuhrmann V, Madl C, Silberhumer G, Muller C. Prognostic significance of the hepatopulmonary syndrome in patients with cirrhosis. Gastroenterology 2003; 125: 1042-52.
51. Abrams GA, Jaffe CC, Hoffer PB, Binder HJ, Fallon MB. Diagnostic utility of contrast echocardiography and lung perfusion scan in patients with hepatopulmonary syndrome. Gastroenterology 1995; 109: 1283-8.

52. DuBrock HM, Krowka MJ, Forde KA, Krok K, Patel M, Sharkoski T, et al. Clinical Impact of Intrapulmonary Vascular Dilatation in Candidates for Liver Transplant. Chest 2018; 153: 414-26.

53. Fallon MB, Krowka MJ, Brown RS, Trotter JF, Zacks S, Roberts KE, et al. Impact of hepatopulmonary syndrome on quality of life and survival in liver transplant candidates. Gastroenterology 2008; 135: 1168-75.

54. Rolla G, Brussino L, Colagrande P, Scappaticci E, Morello M, Bergerone $\mathrm{S}$, et al. Exhaled nitric oxide and impaired oxygenation in cirrhotic patients before and after liver transplantation. Annals Intern Med 1998; 129: $375-8$.

55. Fallon MB, Abrams GA, Luo B, Hou Z, Dai J, Ku DD. The role of endothelial nitric oxide synthase in the pathogenesis of a rat model of hepatopulmonary syndrome. Gastroenterology 1997; 113: 606-14.

56. Luo B, Liu L, Tang L, Zhang J, Ling Y, Fallon MB. ET-1 and TNF-alpha in HPS: analysis in prehepatic portal hypertension and biliary and nonbiliary cirrhosis in rats. Am J Physiol Gastrointest Liver Physiol 2004; 286: G294-303.

57. Ling Y, Zhang J, Luo B, Song D, Liu L, Tang L, et al. The role of endothelin-1 and the endothelin $\mathrm{B}$ receptor in the pathogenesis of hepatopulmonary syndrome in the rat. Hepatology (Baltimore, Md) 2004; 39: 1593-602.

58. Tang L, Luo B, Patel RP, Ling Y, Zhang J, Fallon MB. Modulation of pulmonary endothelial endothelin $B$ receptor expression and signaling: implications for experimental hepatopulmonary syndrome. Am J Physiol Lung Cell Mol Physiol 2007; 292: L1467-1472.

59. Carter EP, Hartsfield CL, Miyazono M, Jakkula M, Morris KG, Jr., McMurtry IF. Regulation of heme oxygenase-1 by nitric oxide during hepatopulmonary syndrome. Am J Physiol Lung Cell Mol Physiol 2002; 283: L346-53.

60. Nunes H, Lebrec D, Mazmanian M, Capron F, Heller J, Tazi KA, et al. Role of nitric oxide in hepatopulmonary syndrome in cirrhotic rats. Am J Respir Crit Care Med 2001; 164: 879-85.

61. Zhang HY, Han DW, Wang XG, Zhao YC, Zhou X, Zhao HZ. Experimental study on the role of endotoxin in the development of hepatopulmonary syndrome. World J Gastroenterol 2005; 11: 567-72.

62. Zhang J, Yang W, Luo B, Hu B, Maheshwari A, Fallon MB. The role of $\mathrm{CX}_{3} \mathrm{CL} 1 / \mathrm{CX}_{3} \mathrm{CR} 1$ in pulmonary angiogenesis and intravascular monocyte accumulation in rat experimental hepatopulmonary syndrome. J Hepatol 2012; 57: 752-8.

63. Zhang J, Luo B, Tang L, Wang Y, Stockard CR, Kadish I, et al. Pulmonary angiogenesis in a rat model of hepatopulmonary syndrome. Gastroenterology 2009; 136: 1070-80.

64. Hales MR. Multiple small arteriovenous fistulae of the lungs. Am J Pathol 1956; 32: 927-43.

65. Krowka MJ, Tajik AJ, Dickson ER, Wiesner RH, Cortese DA. Intrapulmonary vascular dilatations (IPVD) in liver transplant candidates. Screening by two-dimensional contrast-enhanced echocardiography. Chest 1990; 97: 1165-70.

66. Palma DT, Philips GM, Arguedas MR, Harding SM, Fallon MB. Oxygen desaturation during sleep in hepatopulmonary syndrome. Hepatology (Baltimore, Md) 2008; 47: 1257-63.

67. Pascasio JM, Grilo I, Lopez-Pardo FJ, Ortega-Ruiz F, Tirado JL, Sousa JM, et al. Prevalence and severity of hepatopulmonary syndrome and its influence on survival in cirrhotic patients evaluated for liver transplantation. Am J Transplant 2014; 14: 1391-9.

68. Kochar R, Tanikella R, Fallon MB. Serial pulse oximetry in hepatopulmonary syndrome. Dig Dis Sci 2011; 56: 1862-8.

69. Gómez FP, Martínez-Pallí G, Barberà JA, Roca J, Navasa M, RodríguezRoisin R. Gas exchange mechanism of orthodeoxia in hepatopulmonary syndrome. Hepatology (Baltimore, Md) 2004; 40: 660-6.

70. Arguedas MR, Singh H, Faulk DK, Fallon MB. Utility of pulse oximetry screening for hepatopulmonary syndrome. Clin Gastroenterol Hepatol 2007; 5: 749-54. 
71. Lima BL, Franca AV, Pazin-Filho A, Araujo WM, Martinez JA, Maciel BC, et al. Frequency, clinical characteristics, and respiratory parameters of hepatopulmonary syndrome. Mayo Clin Proc 2004; 79: 42-8.

72. Grilo I, Pascasio JM, Lopez-Pardo FJ, Ortega-Ruiz F, Tirado JL, Sousa JM, et al. Hepatopulmonary syndrome: which blood gas analysis criteria and position should we use for diagnosis? Revista espanola de enfermedades digestivas 2017; 109: 843-9.

73. Tonelli AR, Naal T, Dakkak W, Park MM, Dweik RA, Stoller JK. Assessing the kinetics of microbubble appearance in cirrhotic patients using transthoracic saline contrast-enhanced echocardiography. Echocardiography (Mount Kisco, NY) 2017; 34: 1439-46.

74. Abrams GA, Nanda NC, Dubovsky EV, Krowka MJ, Fallon MB. Use of macroaggregated albumin lung perfusion scan to diagnose hepatopulmonary syndrome: a new approach. Gastroenterology 1998; 114: 305-10.

75. Krowka MJ, Wiseman GA, Burnett OL, Spivey JR, Therneau T, Porayko MK, et al. Hepatopulmonary syndrome: a prospective study of relationships between severity of liver disease, $\mathrm{PaO}(2)$ response to $100 \%$ oxygen, and brain uptake after (99m)Tc MAA lung scanning. Chest 2000; 118(3):615-624.

76. Arguedas MR, Abrams GA, Krowka MJ, Fallon MB. Prospective evaluation of outcomes and predictors of mortality in patients with hepatopulmonary syndrome undergoing liver transplantation. Hepatology (Baltimore, Md) 2003; 37: 192-7.

77. Koksal D, Kacar S, Koksal AS, Tufekcioglu O, Kucukay F, Okten S, et al. Evaluation of intrapulmonary vascular dilatations with high-resolution computed thorax tomography in patients with hepatopulmonary syndrome. J Clin Gastroenterol 2006; 40: 77-83.

78. Krowka MJ, Fallon MB, Kawut SM, Fuhrmann V, Heimbach JK, Ramsay MA, et al. International Liver Transplant Society Practice Guidelines: Diagnosis and Management of Hepatopulmonary Syndrome and Portopulmonary Hypertension. Transplantation 2016; 100: 1440-52.

79. Grady K, Gowda S, Kingah P, Soubani AO. Coil embolization of pulmonary arteries as a palliative treatment of diffuse type I hepatopulmonary syndrome. Respir Care 2015; 60: e20-25.

80. Poterucha JJ, Krowka MJ, Dickson ER, Cortese DA, Stanson AW, Krom RA. Failure of hepatopulmonary syndrome to resolve after liver transplantation and successful treatment with embolotherapy. Hepatology (Baltimore, Md) 1995; 21: 96-100.

81. Krowka MJ, Mandell MS, Ramsay MA, Kawut SM, Fallon MB, Manzarbeitia C, et al. Hepatopulmonary syndrome and portopulmonary hypertension: a report of the multicenter liver transplant database. Liver Transplant 2004; 10: 174-82.

82. Gupta S, Castel H, Rao RV, Picard M, Lilly L, Faughnan ME, et al. Improved survival after liver transplantation in patients with hepatopulmonary syndrome. Am J Transplant 2010; 10: 354-63.

83. Iyer VN, Swanson KL, Cartin-Ceba R, Dierkhising RA, Rosen CB, Heimbach JK, et al. Hepatopulmonary syndrome: favorable outcomes in the MELD exception era. Hepatology (Baltimore, Md) 2013; 57: 2427-35.

84. Galie N, Humbert M, Vachiery JL, Gibbs S, Lang I, Torbicki A, et al. "2015 ESC/ERS Guidelines for the diagnosis and treatment of pulmonary hypertension. The Joint Task Force for the Diagnosis and Treatment of Pulmonary Hypertension of the European Society of Cardiology (ESC) and the European Respiratory Society (ERS)." Nazzareno Galiè, Marc Humbert, Jean-Luc Vachiery, Simon Gibbs, Irene Lang, Adam Torbicki, Gérald Simonneau, Andrew Peacock, Anton Vonk Noordegraaf, Maurice Beghetti, Ardeschir Ghofrani, Miguel Angel Gomez Sanchez, Georg Hansmann, Walter Klepetko, Patrizio Lancellotti, Marco Matucci, Theresa McDonagh, Luc A. Pierard, Pedro T. Trindade, Maurizio Zompatori and Marius Hoeper. Eur Respir J 2015; 46: 903-975. Eur Respir J 2015; 46: 1855-6.
85. Krowka MJ, Edwards WD. A spectrum of pulmonary vascular pathology in portopulmonary hypertension. Liver Transplant 2000; 6: 241-2.

86. Edwards BS, Weir EK, Edwards WD, Ludwig J, Dykoski RK, Edwards JE. Coexistent pulmonary and portal hypertension: morphologic and clinical features. J Am Coll Cardiol 1987; 10: 1233-8.

87. Robalino BD, Moodie DS. Association between primary pulmonary hypertension and portal hypertension: analysis of its pathophysiology and clinical, laboratory and hemodynamic manifestations. J Am Coll Cardiol 1991; 17: 492-8.

88. Kawut SM, Krowka MJ, Trotter JF, Roberts KE, Benza RL, Badesch DB, et al. Clinical risk factors for portopulmonary hypertension. Hepatology (Baltimore, Md) 2008; 48: 196-203.

89. Kim WR, Krowka MJ, Plevak DJ, Lee J, Rettke SR, Frantz RP, et al. Accuracy of Doppler echocardiography in the assessment of pulmonary hypertension in liver transplant candidates. Liver Transplant 2000; 6: 453-8.

90. Raevens S, Colle I, Reyntjens K, Geerts A, Berrevoet F, Rogiers X, et al. Echocardiography for the detection of portopulmonary hypertension in liver transplant candidates: an analysis of cutoff values. Liver Transplant 2013; 19: 602-10.

91. Porres-Aguilar M, Zuckerman MJ, Figueroa-Casas JB, Krowka MJ. Portopulmonary hypertension: state of the art. Ann Hepatol 2008; 7: 321-30.

92. Hadengue A, Benhayoun MK, Lebrec D, Benhamou JP. Pulmonary hypertension complicating portal hypertension: prevalence and relation to splanchnic hemodynamics. Gastroenterology 1991; 100: 520-8.

93. Krowka MJ, Swanson KL, Frantz RP, McGoon MD, Wiesner RH. Portopulmonary hypertension: Results from a 10-year screening algorithm. Hepatology (Baltimore, Md) 2006; 44: 1502-10.

94. Colle IO, Moreau R, Godinho E, Belghiti J, Ettori F, Cohen-Solal A, et al. Diagnosis of portopulmonary hypertension in candidates for liver transplantation: a prospective study. Hepatology (Baltimore, Md) 2003; 37: 401-9.

95. Kuo PC, Plotkin JS, Johnson LB, Howell CD, Laurin JM, Bartlett ST, et al. Distinctive clinical features of portopulmonary hypertension. Chest 1997; 112: 980-6.

96. Galie N, Humbert M, Vachiery JL, Gibbs S, Lang I, Torbicki A, et al. 2015 ESC/ERS Guidelines for the diagnosis and treatment of pulmonary hypertension: The Joint Task Force for the Diagnosis and Treatment of Pulmonary Hypertension of the European Society of Cardiology (ESC) and the European Respiratory Society (ERS): Endorsed by: Association for European Paediatric and Congenital Cardiology (AEPC), International Society for Heart and Lung Transplantation (ISHLT). Eur Respir J 2015; 46: 903-75.

97. Montani D, Savale L, Natali D, Jais X, Herve P, Garcia G, et al. Long-term response to calcium-channel blockers in non-idiopathic pulmonary arterial hypertension. Eur Heart J 2010; 31: 1898-907.

98. Provencher S, Herve P, Jais X, Lebrec D, Humbert M, Simonneau G, et al. Deleterious effects of beta-blockers on exercise capacity and hemodynamics in patients with portopulmonary hypertension. Gastroenterology 2006; 130: 120-6.

99. Krowka MJ, Plevak DJ, Findlay JY, Rosen CB, Wiesner RH, Krom RA. Pulmonary hemodynamics and perioperative cardiopulmonary-related mortality in patients with portopulmonary hypertension undergoing liver transplantation. Liver Transplant 2000; 6: 443-50.

How to cite this article: Benz F, Mohr R, Tacke F, Roderburg C. Pulmonary complications in patients with liver cirrhosis. J Transl Intern Med 2020; 8: 150-8. 